\title{
Gender-Based Political Violence in Mexico: A Complex Assignment
}

\author{
Dra. Lizbeth Gabriela Corral Limas ${ }^{*}$, Master Alma Yolanda Morales Corral ${ }^{2}$, Master Verónica Ofelia Lozano Sandoval ${ }^{3}$
}

${ }^{1}$ Doctor in Administration, Master in Administration with Specialty in Human Resources, and Bachelor Degree in Public Administration and Political Science, Professor of Autonomous University of Chihuahua, Faculty of Political and Social Sciences, Campus Juarez, Chihuahua, México

${ }^{2}$ Master in Administration and Bachelor Degree in Law, Professor of Autonomous University of Chihuahua, Faculty of Political and Social Sciences, Campus Juarez, Chihuahua, México

${ }^{3}$ Master in Administration, Master in Journalist and Bachelor Degree in Communication, Professor of Autonomous University of Chihuahua, Faculty of Political and Social Sciences, Campus Juarez Chihuahua, México

DOI: $10.36348 /$ sjhss.2020.v05i08.003 $\quad$ | Received: 10.08 .2020 | Accepted: 18.08 .2020 | Published: 20.08 .2020

*Corresponding author: Dra. Lizbeth Gabriela Corral Limas

Abstract

This article analyzes the phenomenon of gender-based political violence in Mexico, which has impacted and affected the political participation of women in the country, which began in the 19th century, and which represents not only an existing problem, but rooted and recurring. Women in Mexican politics have been historically invisible and have been limited in the exercise of their political-electoral rights due to various social, cultural, partisan, structural, institutional circumstances, among others, that have favored the existence of a considerable and very marked gap with respect to men in this area. Hence the importance of the issue being addressed and eradicated, since it is a practice that restricts women and complicates their full development. In this work, political violence is conceptualized, and among other points, it is analyzed how it is presented, how it can be detected, what are the behaviors that it implies, some cases that show it, what are the rights of the victims and what institutions, instances, organizations, pacts, protocols, conventions and laws, both national and international, provide attention, channeling and solution to various aspects related to political violence against women on the basis of gender and some of the actions that have been taken, aimed at attend to it, sanction it, and prevent it. A cross-sectional documentary investigation was carried out to analyze the historical development of political violence up to the conditions in which it is currently manifested in Mexico.

Keywords: political violence, gender violence, politics, discrimination, women, Mexico.

Copyright @ 2020: This is an open-access article distributed under the terms of the Creative Commons Attribution license which permits unrestricted use, distribution, and reproduction in any medium for non-commercial use (NonCommercial, or CC-BY-NC) provided the original author and source are credited.

\section{INTRODUCTION}

"Violence is not just killing another. There is violence when we use a degrading word, when we make gestures to denigrate another person, when we obey because there is fear. Violence is much subtler, much deeper", a significant phrase of the Hindu writer and philosopher Jiddu Krishnamurti, who throughout his life made multiple reflections on various aspects of existence and the human condition [1].

Violence is the intentional use of physical force, threats against oneself, another person, a group, or a community that results in or is very likely to result in trauma, psychological harm, developmental problems, or death [2].

The United Nations defines violence against women as "any act of gender-based violence that results, or may result in physical, sexual or psychological harm to women, including threats of such acts, coercion or arbitrary deprivation of freedom, whether they occur in public or private life" [3].

In Mexico, the political participation of women did not start in 1953, there was already a long way to go, thanks to women such as Leona Vicario, Josefa Ortiz, Elvia Carrillo Puerto and many more, however, the path has not been smooth. To this day they continue to face obstacles to which one more face is added to the polyhedron of gender violence: genderbased political violence [4].

Political violence against women includes all those actions or omissions of people, servants or public servants who address a woman because she is a woman (based on gender), have a differentiated impact on them or disproportionately affect them, with the aim or result of impairing or nullifying their political-electoral rights, including the exercise of office [5]. 
According to the National Human Rights Commission (CNDH), the type of political violence against women can include, among others, physical, psychological, symbolic, sexual, patrimonial, economic or feminicidal violence, and attacks against women for being women have as their background is disqualification and a systematic and undifferentiated distrust of their abilities and possibilities of doing a good job or winning an election. In order to be able to detect political violence against women on the basis of gender, it is essential to consider that it is normalized and, therefore, invisible, and can constitute practices so common that they are not questioned [5].

Two elements are essential to consider that an act of violence is based on gender: 1) When violence is directed at a woman because she is a woman: that is, when the attacks are especially directed against women because of their womanhood and for what they represent in symbolic terms, under conceptions based on stereotypes. Even, often the act is directed towards what is implied by the "feminine" and the roles that are normally assigned to women, and, 2) When violence has a differentiated impact on women: that is: a) When the action or omission affects women differently than men or whose consequences are aggravated by the condition of being a woman; and/or, b) When it affects them disproportionately. This last element is responsible for those events that affect women in a greater proportion than men [5].

Political violence can be directed towards: a) One or more women (in politics), b) Relatives or people close to the victim, and, c) A group of people or the community (for example: I work for you); and it can take place in any sphere: a) Political, economic, social, cultural, civil, b) Within the family or domestic unit or in any interpersonal relationship, and, c) In the community, in a political party or institution. That is, it includes the public and private spheres [5].

The forms or types of political violence can be: physical, psychological, symbolic, sexual, patrimonial, economic and feminicidal; It can affect any person or group of people, men or women, including, such as: a) Members of political parties; b) Applicants, precandidates, candidates for positions of popular election or party leadership; c) Public servants, government authorities; d) Servers or authorities of electoral institutions; and, e) Representatives of the media, as well as the State and its agents. It should be noted that women can also exercise gender-based political violence against other women [5].

\section{METHOD}

The type of the research was a cross-sectional documentary investigation, wich was carried out to discover how the political violence against women in
Mexico has manifested itself from the earliest indications to the present day.

\section{RESULTS AND DISCUSSION}

To identify political violence against women on the basis of gender, it is necessary to verify that the following five elements are present: 1) The act or omission is based on gender elements, that is: I. address a woman for being a woman, II. have a differentiated and disadvantageous impact on women; and/or, III. affects them disproportionately; 2) Has the purpose or result to impair or nullify the recognition, enjoyment and / or exercise of women's political-electoral rights; 3 ) It occurs within the framework of the exercise of political-electoral rights or in the exercise of a public office, (regardless of the fact that it manifests itself in the public or private sphere, in the political, economic, social or cultural sphere , civil, etc., takes place within the family or domestic unit or in any interpersonal relationship, in the community, in a political party or institution); 4) Be symbolic, verbal, patrimonial, economic, physical, sexual and/or psychological; 5) Be perpetrated by any person or group of people -men or women-, in particular: members of political parties, aspirants, pre-candidates, candidates for positions of popular election or party leadership; public servants, government authorities, officials or authorities of electoral institutions; representatives of the media; the state or its agents [5].

The manifestations of political violence can occur when: a) They cause the death of women for participating in politics (femicide/feminicide); b) They physically assault one or more women with the object or result of diminishing or nullifying their political rights; c) They sexually assault one or more women or cause abortion, with the object or result of diminishing or nullifying their political rights; d) Make proposals, touches, approaches or unwanted invitations, of a sexual nature, that influence the political aspirations of women and/or the conditions or environment where political and public activity takes place; e) Threaten, scare or intimidate in any way one or more women and/or their families, and whose purpose or result is to nullify their political rights, including resignation from the post or function they exercise or postulate; f) Restrict or annul women's right to free and secret voting; g) Defame, slander, insult or carry out any expression that denigrates women in the exercise of their political functions, based on gender stereotypes, with the objective or the result of undermining their public image and/or limiting their political rights; h) Threaten, scare or intimidate in any way one or more women and/or their families, and whose purpose or result is to undermine their political rights; i) Threaten, attack or incite violence against human rights defenders for gender reasons, or against those defenders who protect the rights of women; j) Unduely use criminal law without foundation, in order to criminalize the work of human rights defenders and/or paralyze or delegitimize the causes they pursue; k)They 
discriminate against women in the exercise of their political rights, for being pregnant, childbirth, postpartum, maternity leave or any other justified leave, according to the applicable regulations; 1)They damage, in any way, elements of the women's electoral campaign, preventing electoral competition from developing under conditions of equality; m) Provide electoral institutes with false information or incomplete information on the identity or sex of the candidate and designated person, in order to impede the exercise of women's political rights; n) Restrict the political rights of women due to the application of traditions, customs or internal legal systems that violate current human rights regulations; o) Disseminate images, messages or disclose information about women exercising their political rights, by any physical or virtual means, in political-electoral propaganda or in any other that, based on gender stereotypes, transmit and/or reproduce relations of domination, inequality and discrimination against women, with the aim of undermining their public image and/or limiting their political rights; p) Hinder or impede women's access to justice to protect their political rights; q) Impose unjustified and/or abusive sanctions, preventing or restricting the exercise of their political rights under equal conditions; r) Arbitrarily limit or deny the use of any resource and/or attribution inherent to the political position held by women, preventing the exercise of the position on equal terms; s) Forcing women to reconcile or desist when they are in an administrative or judicial process in defense of their political rights; t) Avoid, by any means, that women in the exercise of their political rights attend any activity that involves decision-making, on equal terms; u) Provide women, in the exercise of their political rights, with false, erroneous or imprecise information and/or omit information that induces the inadequate exercise of their political rights on equal terms; and, v) They restrict the use of the word of women in the exercise of their political rights, preventing the right to speak, in accordance with the applicable regulations and on equal terms. w) Impose by gender stereotypes the performance of activities and tasks outside the functions and attributions of their position or position, which have as a result the limitation of the exercise of the political function [5].

According to the Model Inter-American Law on Political Violence Against Women, items t) to w) are considered serious offenses and very serious offenses $h$ ) to s), while a) to g) are considered crimes [5].

\section{How can gender-based political violence and the behaviors it involves be detected?}

To identify political violence, it is necessary to ask whether the act or omission: 1 . Is it directed at a woman because she is a woman? Does it affect them disproportionately?, Does it have a differentiated impact for women compared to men?; 2. Does it hinder or annul the recognition, enjoyment and / or exercise of your political-electoral rights?; and, 3. Does it occur within the framework of the exercise of their politicalelectoral rights or in the exercise of public office?

According to the Specialized Prosecutor for the Attention of Electoral Crimes (FEPADE) during the 2014-2015 electoral process in Mexico, in the entities of Baja California, Chiapas, State of Mexico, Guerrero, Morelos, Oaxaca, Sonora and Tabasco were presented cases of political gender violence against people who served as pre-candidates, candidates, party leaders, campaign coordinators, collaborators, as well as the candidates relatives [6].

Women are currently in university classrooms, they vote, they elect and they are elected to political office. They hold public office and work in the private sector. They have extensive training and discursive capacity, they have ensured public transit. They express their preferences of all kinds. They are the highest rate of readers and consumers of culture and university extension. Against the old prejudices they have criteria and presence, however, in reality they still have to fight battles, one of them is the phenomenon of resistance to women's political activity: political violence based on gender [4].

Assaults, insults, threats, take away or do not give them the resources to carry out their functions, pressure them to resign from their elected or appointment positions, some have even lost their lives, due to the fact that they were women who intended to exercise your political rights [4].

\section{Identify and make visible political violence against}

Among the aspects that can be considered to identify political violence are: society's attitudes towards women, which do not stimulate their participation in decision-making, the prevalence of stereotypes in higher education careers that women wish to pursue, the relationship with what is known as the "glass ceiling", when women face a series of implicit limits or barriers (not visible or tangible) that are difficult to cross, preventing them from continuing to rise in their careers [4].

"Concrete ceilings are those that women break when they overcome self-imposed limitations, based on prejudices and beliefs about their competences and abilities to contribute to politics"; "Not all criticism of women who participate in electoral campaigns is political gender violence [...] for this behavior to be constituted, the attack must be based on gender elements, that is, targeting a woman for being a woman, having a differentiated impact against it and affect it disproportionately [4]".

Political violence against women has recently been criminalized at the federal level, this has been possible thanks to various struggles in the legislative processes and in the incidence of civil society organizations. However, in most states, the concept has 
not been included in their laws and also requires greater visibility by government institutions to generate actions for their care and prevention, as well as key actions to strengthen the participation of women. Efforts to carry out research and carry out actions for training through education have had an important basis in civil society organizations [7].

It is necessary to move towards policies that guarantee women the exercise of their human rights, particularly to participate in the country's public and political decisions.

\section{Cases evidencing political violence against women in Mexico}

In various Mexican state entities there is evidence regarding political practices, rooted among the leaders and militants of political parties, which can be classified as manifestations of harassment and / or political violence against women [8].

In Chiapas, Guerrero, Oaxaca, Baja California, San Luis Potosí, Hidalgo, Puebla, Querétaro, Sonora or Tamaulipas, for example, situations have been found in which pressure has been exerted on the electoral authorities to register candidates without complying with what requires the law (Oaxaca or Chiapas); resistance to promote the political career of women on an equal footing with that of men [8].

The use of degrading phrases is also used in speeches and on banners in full electoral campaigns (Sinaloa, Baja California); claims that "parity cannot be above merit or democracy" (Oaxaca); allegations that "there are no women who want to be candidates" (Oaxaca, Chiapas), "since while they have a leadership...they have spent it cooking at home" (Oaxaca) and accusations of kidnappings, beatings, lashes against the candidates and/or elected when they want to exercise their positions. In Chiapas, Guerrero and Oaxaca, in addition, there was pressure for the removal of the women elected to the municipal Presidencies and Syndicatures, so that they do not participate in the organs that they should integrate and, therefore, that they are not part of the taking of decisions, use of resources and direction of your municipality. Although they acquire particular specificities, the combination of these community practices with the institutional demands of the political party system has confronted many indigenous women with a universe of new forms of violence [8].

When politicians have had no choice but to place women in the candidacies, even pressured by the electoral rules that included gender parity in the Constitution, they have often selected "submissive candidates", who they think they can control, with whom they have some direct family, business or friendship bond. In this way, many Mexican women depend on the support of the party's leaders and dominant groups to obtain a candidacy, since it is they who determine the partisan offer in each district to compete. In some cases, they consider that female candidates are a punishment and the cause of their electoral defeat, as the PRI governor-elect declared in the last elections in Hidalgo. In small districts and in many Municipal Presidencies, the idea is maintained that "the candidacy is mine", of those men (local chiefs) who have repeatedly competed and won in that district. In this way, the parties continue to place the candidates in the "losing districts", that is, in those that do not usually win, despite the fact that it has been expressly prohibited since 2014 [8].

Leaders often do not allow women candidates and/or elected to make decisions related to the campaign: they do not allow them to choose the people who will act as their collaborators, they deny them access to relevant information related to their position; they cannot define the topics on which to debate and require them to promote certain projects and how to vote in each case [8].

An example of political violence that was very significant at the time was the so-called "Las Juanitas de San Lázaro", which was an attempt to circumvent gender equality, and which occurred after the elections and by protesting in the Chamber of Deputies in September 2009, when ten people, 8 women and two men, applied for leave at the time. Women would be replaced by their male alternates and men by women. Of the total, four women and two men belonged to the PVEM (Green Ecological Party of Mexico), two women to the PRI (Institutional Revolutionary Party), one woman to the PRD (Party of the Democratic Revolution) and another woman to the PT (Labor Party). One of them left the seat to her husband, another to her brother, and the others to people with certain family, work or friendship relationships with leaders of their respective parties. There was already talk, at the time, of modifying the law in the sense that substitutes were of the same sex, to avoid these practices, that is, the attempt to violate the spirit of equity in the distribution of deputations that arose from the Federal Code of Electoral Institutions and Procedures (COFIPE). This case was a test of the cupular arrangements of the political parties to the detriment of the female presence in political positions, but several voices of women politicians and representatives of institutions such as INMUJERES (National Institute of Women) and IFE (Institute Federal Electoral) declared that the law should be reformulated or clarified so that this would not happen again [9].

As another revealing example of more recent political violence, it was that of "Las Manuelitas de Chiapas", which occurred in September 2018, and where the phenomenon of the "Juanitas" of 2009 was basically repeated, but now in the State of Chiapas, where it was denounced that at least 43 local deputies 
and councilors in various municipalities of Chiapas and some multi-member legislators, were pressured to resign and leave their place to a man; These women, on this occasion, have been called "Manuelitas", alluding to the governor, senator with a state license, Manuel Velasco Coello. On this occasion, the electoral authority approved a point of agreement for the political spaces for women to be redistributed and reallocated; the federal electoral authority attracted the case and promoted a solution with a gender perspective, pending to define what the investigation would be like to sanction those responsible for the threats and coercions, because in violation of the law, they also politically violated women [10].

One more case of political violence directed at women due to the fact that they are women is the case of the Municipality of San Bartolo, Coyotepec, Oaxaca, in which, in 2014, elections for the municipal presidency, councilors and unions were held. In the General Community Assembly, the nomination of women in the short list of candidates for the election of the municipal presidency and the union was not allowed. It was argued that under the current internal regulatory system, women were not allowed to apply to these positions in the community. The result was that only men filled the ten available positions. After electoral authorities -both administrative and judicial declared the validity of the elections despite discrimination against women, the Superior Chamber of the TEPJF considered that these authorities had not correctly interpreted the principle of equality, which must also be observed in the elections held under indigenous regulatory systems and, therefore, the constitutional principle of the universality of suffrage and the political participation of women had been violated, for which reason the election of members of the City Council in said Municipality was declared null and void. Consequently, the local state electoral and, therefore, the constitutional principle of the universality of suffrage and the political participation of women had been violated, for which reason the election of members of the City Council in said Municipality was declared null and void. Consequently, the local state electoral institute and the members of the community were linked to carry out in the extraordinary election "all the necessary actions to guarantee the observance of the principles of certainty, legality, independence, impartiality, objectivity and, especially, the participation of women and men on equal terms, in addition to the fact that they must inform the members of that community about the rights to vote and be elected by women, in order to promote conditions of substantive equality in the development of the election of councilors [6]".

Another example is that of the election of Councilors to the city council of San Juan Cotzocón, Mixe, Oaxaca, which took place in 2011. Although the approaches known by the Superior Chamber of the
TEPJF were not strictly of violence against women, when studying the file, found that there were acts of discrimination and violence against them. In the Emiliano Zapata Community of said Municipality, several men tried to lynch the treasurer of that agency, on the grounds that the men "ruled" there. A supposed professor ordered the municipal official to be imprisoned in a dungeon saying these words: "This old woman has not learned that in this town we send men", "How are those ladies going to govern us". Along with two other women, the violated woman headed the government of that municipal agency. A woman "asked for permission", "they granted it", participated in the process of electing authorities of the municipal agency Emiliano Zapata, and won. On the day of the election, the elected municipal agent took office, and appointed two more women, one as her secretary and the other as treasurer. However, the "annoyance" of the nonconformists was due to the fact that in that Mixe town a woman had never ruled [6].

\section{Political violence against women prevents equality in elections}

It is necessary to modify the General Law on Electoral Crimes so that political violence against women is classified as an electoral crime, said the teacher in Social Studies from the Metropolitan Autonomous University, Lorena Vázquez Correa. In an investigation published by the Belisario Domínguez Institute of the Senate of the Republic, the specialist pointed out that it is necessary to legislate political violence against women so that women can develop on equal terms with men in the political-electoral sphere. According to the study, the law on electoral crimes does not typify political gender violence, so it has not been an easy task for the authorities to prosecute and sanction these behaviors, this led to the agencies creating the Protocol to Address the Political Violence against Women in 2016 [11].

When presenting the document at the congress of the Mexican Society for Electoral Studies (SOMEE) that took place in August in Mexico City, Vázquez Correa highlighted that 6 initiatives on the matter have been presented in the Senate and on March 9, approved a minute that has not been ratified by the Chamber of Deputies. To address cases of violence against female candidates or elected women, the Specialized Prosecutor for Electoral Crime (FEPADE), of the Office of the Attorney General of the Republic (PGR), has classified as electoral violence against women those electoral crimes in which the victim of the act is a woman or when they are disproportionately affected. The FEPADE detected between 2013 and 2016, 416 files (preliminary investigations and investigation folders) that could constitute political gender violence. Of these, more than half (53.1 percent) occurred in 2016; and between 2012 and 2016, 156 cases of violence have been detected, the investigation indicates [11]. 
Among the cases detected by the authority, three stand out against the political-electoral rights of the gay lesbian community; 45 cases of violence against elected women who were in office; and 10 cases of events that affected the political rights of indigenous people [11].

\section{Victims' Rights}

The categorization of violence against women as a human rights issue has important consequences. The recognition that violence against women is a violation of human rights clarifies the binding norms that impose on States the obligations to prevent, eradicate and punish such acts of violence and hold them accountable in the event that they do not comply with such obligations. These emanate from the duty of the States to take measures to respect, protect, promote and fulfill human rights. Thus, the demand that the State take all appropriate measures to respond to violence against women leaves the realm of discretion and becomes a legally protected right [5].

Until the beginning of 2020, political violence against women on the basis of gender was not recognized as criminal, electoral or administrative sanctionable conduct, it could be sanctioned through the configuration of other behaviors that are contemplated and generate responsibilities for those tracks. At the state level, only 28 entities have incorporated the modality of political violence against women in one or some of the following regulations: Political Constitution, State Law on Women's Access to a Life Free of Violence, Electoral Law and/or Penal Code [5].

Sentences and actions aimed at sanctioning, attending to and preventing political violence based on gender

On April 18, 2018, the Complaints and Complaints Commission of the National Electoral Institute (INE) issued precautionary measures for the first time to download expressions of gender-based political violence from Facebook and an internet blog [4].

FEPADE is in charge of promoting, guaranteeing and protecting the exercise of human rights of victims and offenders in cases of gender-based political violence, despite not having specific legislation. The institutions in charge of handling cases of political gender violence are: Electoral Tribunal of the Federal Judicial Branch (TEPJF); National Electoral Institute (INE), and the Specialized Prosecutor for the Attention of Electoral Crimes (FEPADE)[4].

Public institutions such as the TEPJF, the INE, among others, built and signed the Protocol to Address Political Violence Against Women. There have been 106 cases of gender-based political violence in 2018, 16 assassinated candidates and 10 cases of events that directly harm the political-electoral rights of indigenous women [4].

Institutions for attention, channeling and solving cases related to political violence against women on the basis of gender

Among the institutions in charge of handling issues related to political violence against women in Mexico, are: A. National Electoral Institute (INE). B. Specialized Prosecutor's Office for Attention to Electoral Crimes (FEPADE). C. Electoral Court of the Federal Judicial Power (TEPJF). D. Undersecretariat of Human Rights (CNDH). E. Executive Commission for Attention to Victims (CEAV). F. Special Prosecutor for Crimes of Violence Against Women and Trafficking in Persons (FEVIMTRA). G. Centers of Justice for Women (CONAVIM). H. National Institute of Women (INMUJERES). I. National Council to Prevent Discrimination (CONAPRED). J. National Human Rights Commission (CNDH State Human Rights Institutions). Each with different powers and ranges of action.

\section{Instances, agencies and laws}

To protect and defend mexican women, victims of political violence, there are various instances, organizations and laws, both national and international, that already contemplate political violence, as well as sanctions and recommendations in this regard, such as:

\section{Political Constitution of the United Mexican States}

The Political Constitution contemplates, in the following articles, among others, these considerations: Art. 1 Any discrimination motivated by ethnic or national origin, gender, age, disabilities, health conditions, religion, $[. .$.$] that violates human dignity and$ is intended to nullify or impair rights and is prohibited liberties of people [12].

Art. 4 Male and female are equal before the law [12]

Art. 34 Men and women who, having the quality of Mexicans, also meet the following requirements are citizens of the Republic: I. Having reached the age of 18 , and, II. To have an honest way of living [12].

The route taken to achieve the recognition of women's human rights, from the right to vote to achieving parity in the integration of political bodies, has not been an easy one, considering that gender-based political violence appears in the form of rejection and hostility towards women seeking to exercise their political electoral rights. Laws must guarantee the principle of parity; however, resistance to women's participation is currently maintained, despite all progress in this area. They are not always legal causes, but of a social nature, but they obstruct the path towards equality [4]. 


\section{Electoral Court of the Federal Judicial Branch (TEPJF)}

The TEPJF states that electoral political rights are the "prerogatives recognized exclusively to citizens, which empower and ensure their participation in the conduct of public affairs, including the right to vote and to be voted or voted $[\ldots]^{\prime \prime}$

\section{International Covenant on Civil and Political Rights (ICCPR)}

Art. 25. All citizens will enjoy, without any of the distinctions mentioned in art. 2 , and without undue restrictions, of the following rights and opportunities: $[\ldots]$ c) Have equal access to public functions in your country.

\section{Convention on the Elimination of All Forms of Discrimination against Women (CEDAW)}

Art. 7. The States Parties shall take all appropriate measures to eliminate discrimination against women in the public life of the country and, in particular, guaranteeing, on an equal basis with men, the right: a) To vote in all elections and public referendums and be eligible for all bodies whose members are subject to public elections [...].

c) Participate in non-governmental organizations and associations that deal with the public life of the country.

\section{Center for Studies for the Achievement of Gender Equality (CELIG)}

CELIG is a non-partisan technical support body, made up of specialists in the preparation of studies, analyzes and research with a gender perspective, which seeks to contribute and enrich the work of legislators with the aim of promoting the recognition of Women's human rights [4].

On August 3, 2005, the creation of the Center for Studies for the Advancement of Women and Gender Equity (CEAMEG) was published in the Official Gazette of the Federation (DOF). A year later the works formally began; On December 28, 2017, the Decree amending article 49, number 3 , where the center is mentioned as the Center for Studies for the Achievement of Gender Equality, is published in the Official Gazette of the Federation (DOF).

Its objective is to support legislative work objectively, impartially and in a timely manner through analytical information and technical support services that help promote the advancement of women and gender equality. With respect to the CELIG Legal Framework, which is the set of laws, regulations and agreements to which it must adhere in the exercise of the functions entrusted to it, there are: a) Organic Law of the General Congress of the United Mexican States, b ) Statute of the Technical and administrative organization and the career service of the Chamber of
Deputies, c) General Manual of organization of the Chamber of Deputies, and d) General Law of Transparency and Access to Public Information 2015 [4].

Regarding the National Legal Framework on the Human Rights of Women, there are: a) Political Constitution of the United Mexican States; b) Federal Law to prevent and eliminate discrimination, c) General Law on women's access to a life free of violence, d) General Law for equality between women and men, e) General Law to prevent, punish and eradicate crimes related to human trafficking and for the protection and assistance to victims of these crimes, f) General Law on the rights of girls, boys and adolescents, g) Federal Civil Code, and h) Federal Penal Code. On the International Legal Framework in the Field of Women's Human Rights, there is International Human Rights Law, which includes a set of international instruments according to the subject or ownership that is intended to protect, the provisions contemplated in international instruments rights have evolved in parallel, under social demands, in order to protect the human rights of women, where they are located, the Universal Declaration of Human Rights and CEDAW (Convention on the Elimination of all forms of Discrimination against Women) [4].

The CELIG, in its analysis: "Political violence based on gender", presented that, despite the fact that the first article of the Political Constitution of the United Mexican States expressly prohibits all types of discrimination, they continue to be the target of stigmatization by the just being women, which is the habit of designating a role for them in society and that political aggression is the obstacle they face for wanting to exercise their political-electoral rights and access and influence their communities, a situation that does not it has to do with their ideas, proposals, or because they belong to a certain political party, but because they are women [13].

The CELIG study indicates that only five states establish this type of violence in their Constitution, only 18 states mention it in their Electoral Law, in 21 states they contemplate it in the Law of Access of Women to a Life Free of Violence, only 4 states criminalize it in their Penal Code and 3 states have not legislated it in any of their legal frameworks [13].

However, CELIG assured, there is still a long way to go towards equality. Making the problem visible is a good start, because women are still invisible to participate in real decision-making spaces. He attributed the increase in gender-based political violence to the advancement of the female population in public affairs achieved in recent years. The path followed to achieve the recognition of women's human rights starts from the right to vote to the achievement of parity. The 
integration of political bodies has not been easy, considering that this type of gender aggression appears in the form of rejection and hostility towards those who seek to exercise their political-electoral rights. This type of aggression translates into actions or omissions that disproportionately impact or affect one or more women, when participating in political life, not for their preparation or ability, but for the simple fact of being, with the purpose of impairing or nullifying their political-electoral rights, including the exercise of public office [13].

CELIG pointed out that laws must guarantee the principle of parity; however, resistance to female participation is currently maintained, despite all the progress made. It is not always legal causes, but of a social nature, that obstruct the path to equality [13].

\section{Protocol for the Attention of Violence against Women in Reason of Gender}

This Protocol is a benchmark for citizen and inter-institutional action. Instances and authorities involved in dealing with political violence against women on the basis of gender participated in its design and construction, who contributed knowledge and experience from the diversity of their area of responsibility.

The signatory institutions are identified with the interest in strengthening the exercise of women's political-electoral rights, because in that conviction comes the responsibility of the Mexican state, the aspiration of political actors, but, above all, the strengthening and empowerment of a more informed citizenry that is attentive to the demand for respect for their fundamental rights. In the absence of a regulatory framework that specifically regulates this type of violence, the institutions involved proactively designed this action tool.

This commitment includes the Protocol for the Attention of Violence against Women in Reason for Gender 2017. The strength and relevance of the second version of the Protocol lies in the inter-institutional consensus of the construction, homogenization and use of the concept of political violence against women on the basis of gender, which was designed taking as a reference the regulations of national origin - including its jurisprudential framework - and international. In addition to this, this conceptual contribution was nurtured from three fundamental references: the OAS CIM Model Inter-American Law on Political Violence against Women; General Recommendation No. 35 of the UN CEDAW Committee on gender-based violence against women, as well as jurisprudence 48/2016 of the Electoral Court of the Federal Judicial Branch [14].
Model Inter-American Law to Prevent, Punish, and Eradicate Violence against Women in Political Life

The Organization of American States (OAS) brings together the countries of the Western Hemisphere to promote democracy, strengthen human rights, promote economic development, peace, security, cooperation, and advance in the achievement of common interests. The Organization's origins date back to 1890 , when the nations of the region formed the Pan American Union with the aim of strengthening hemispheric relations. This union became the OAS in 1948, after 21 nations adopted its Charter. Since then the Organization has expanded to include the Englishspeaking Caribbean and Canadian nations, and today all the independent nations of North, South, and Central America and the Caribbean make up its 35 member states. The Follow-up Mechanism of the Belém do Pará Convention is a consensual and independent peer review system to examine the progress made by the States Parties in meeting the objectives of the Convention. The Mechanism is financed by voluntary contributions from the States Parties to the Convention and other donors, and the OAS Inter-American Commission of Women (CIM) acts as its Technical Secretary [15].

In 1994, the Inter-American Commission of Women (CIM) promoted the adoption of the InterAmerican Convention to Prevent, Punish, and Eradicate violence against Women, better known as the Convention of Belém do Pará. The Convention entered into force in 1995 and to date has been ratified by 32 States. In 2004, the States Parties to the Convention agreed to create the Follow-up Mechanism to the Belém do Pará Convention (MESECVI) with the objective of monitoring the implementation of the Convention in the countries of the region [15].

In the framework of its work, the MESECVI has recognized the progress made by the States in the prevention and punishment of violence against women in the private sphere, however, it has also repeatedly emphasized that "these actions do not cover all manifestations of violence against women, especially those produced in the public sphere"[1], and has affirmed the need to advance legislation that sanctions violence against women that is perpetrated in the public sphere. In recent years, and in parallel to the greater participation of women in political life in the region, MESECVI identified a growing concern in the region for violence against women perpetrated in political spaces. Linked to this reality, the Committee of Experts of the MESECVI (CEVI) noted the need to strengthen the capacity of the States to respond to this violence, in follow-up to the mandates of the Convention of Belem do Pará. In this context, since 2015, the MESECVI adopted various agreements within its two organs, the Conference of States Parties and the Committee of Experts, which committed us to advance to eradicate the violence that prevents women in the region may 
exercise, under equal conditions and free from discrimination and violence, their political rights, recognized in the Constitutions of the American countries as fundamental rights [15].

Thus, in October 2015, the Sixth Conference of the States Parties to the Convention of Belém do Pará approved the Declaration on Political Violence and Harassment against women, the first comprehensive regional agreement that addresses this issue, in which the signatory countries They declared, among others, the need to promote the adoption of norms for the eradication of political violence and harassment against women. Also, in 2015, the Committee of Experts undertook to contribute to strengthening the capacities of the States Parties to the Convention of Belém do Pará to respond effectively to this violence, paying special attention to legislation, in order to protect and guarantee the exercise of women's political rights, and began the process to prepare this Model Law. This process included specialists from various states in the region who participated in two meetings that were held in Washington, D.C. (February 2015) and in La Paz, Bolivia (May 2016). To all the participants in these meetings we must thank them for their contributions, experience and knowledge about the problems and challenges for addressing them from state institutions. The Model Inter-American Law to Prevent, Punish, and Eradicate Violence against Women in Political Life was adopted by the Committee of Experts of the Follow-up Mechanism of the Convention of Belém do Pará, within the framework of its Thirteenth Meeting, held in Mexico in October 2016 [15].

This Model Law also incorporates the precepts of the International Convention on the Elimination of All Forms of Discrimination against Women (hereinafter CEDAW), in particular, those referring to political rights. CEDAW, in its article 7, indicates the obligation of the States Parties to take all appropriate measures to eliminate discrimination against women in the political and public life of the country and, in particular, to guarantee, under equal conditions with the men, the exercise of political rights. Likewise, in its article 8 , it includes the obligation to take the necessary measures to guarantee, on equal terms, the opportunity to represent your government at the international level and to participate in the work of international organizations. Other international conventions, declarations and agreements attach great importance to the participation of women in political life, such as the Universal Declaration of Human Rights, the International Covenant on Civil and Political Rights, the Convention on the Political Rights of Women, the Declaration of Vienna, paragraph 13 of the Beijing Declaration and Platform for Action, among others. For the purposes of this Model Law, the concept of "public and political life" that is developed in Recommendation number 23 of the CEDAW Committee is relevant, according to which, the political and public life of a country is a broad concept. It refers to the exercise of political power, in particular, the exercise of legislative, judicial, executive and administrative powers. The term encompasses all aspects of public administration and policy formulation and execution at the international, national, regional and local levels; It also covers many aspects of civil society and the activities of organizations, such as political parties, trade unions, professional or industrial associations, women's organizations, community organizations and other organizations that deal with public and political life [15].

In the Americas, the Inter-American Commission on Human Rights has recognized that countries have a long tradition of concern for the political rights of women, which has been reflected in the adoption of various norms that enshrine these rights. The Inter-American Commission of Women has had a fundamental role in shaping this legal framework. Among other norms in favor of women, the CIM promoted the adoption, in 1948, of the Inter-American Convention on the Granting of the Political Rights of Women and, in 1994, the adoption of the Belém do Pará Convention. Likewise, in application of the InterAmerican Program on the Promotion of Women's Human Rights and Gender Equity and Equality (2000), the CIM's main objective is to strengthen the full and equal participation of women in the political life of the country and in decision-making at all levels and, under this framework, he has carried out extensive work. The CIM has verified that the gap persists between the political rights enshrined in the legal framework and the political participation of women in practice. Women continue to face multiple economic, social, institutional and cultural obstacles that seriously limit their participation in political life and, particularly, in government positions. The analyzes have also highlighted progress in women's political participation. As a result of the application of quota laws, and above all parity, the presence of women in the legislative branch has increased in recent years and, today, the Americas is one of the regions of the world with the most parliamentary women. However, it is still far from achieving $50 \%$ of representation, a goal that is set in line with the population weight of women. The participation of women in other state institutions, such as the judiciary, ministerial cabinets, and local governments, is even lower. Research has shown that the presence of women is equally limited in other key areas of political life, such as the leadership of political parties. The problem of underrepresentation of women is a reflection of the discrimination that women face in political life, and the violence that is exerted against them constitutes one of its worst manifestations. As has been reflected in the aforementioned Declaration on Violence and Political Harassment against Women, the greater visibility of this violence is linked to the increase in women's political participation, particularly in representation positions. This, in turn, is a 
consequence of the application of gender quotas and parity, measures that have been adopted by a significant number of countries in the Americas. In other words, given the greater political participation of women, forms of discrimination and violence against them have intensified. The Declaration also recognizes that tolerance towards violence against women in society makes gender-based violence against women invisible in political life, which hinders the development and application of policies to eradicate the problem[15]. $[\ldots]$

\section{Inter-American Model Law to Prevent, Punish, and Eradicate Violence against Women in Political Life Chapter I General Provisions}

Article 1. Purpose The purpose of this law is to prevent and eradicate violence against women in political life in order to ensure that they fully exercise their political rights and participate equally and in conditions of equality in all spaces and functions of political and public life, particularly in government positions.

Article 2. Political rights Political rights include, at least, the following: a) Vote in all elections and public referendums and be eligible for all bodies whose members are subject to public elections; b) Participate jointly in the formulation of government policies and their execution, and hold public office and exercise all public functions at all government levels; c) Participate in non-governmental organizations and associations that deal with the country's public and political life, including political parties and unions. It is considered that the parity of women and men in public and political life implies adopting all the necessary measures to guarantee equal access to all spaces of public life and to all State institutions, particularly to government officials, from the international level to the local level; as well as to ensure equal conditions in the exercise of political rights, that is, free from discrimination and violence based on sex and/or gender [15].

Article 3. Definition of Violence against women in political life. "Violence against women in political life" should be understood as any action, conduct or omission, carried out directly or through third parties that, based on their gender, causes harm or suffering to one or more women, and whose purpose or result is to impair or nullify the recognition, enjoyment or exercise of their political rights. Violence against women in political life may include, but is not limited to, physical, sexual, psychological, moral, economic or symbolic violence.

Article 4. Right of women to a political life free of violence. The right of women to a political life free of violence includes, among other rights: a) The right to be free from all forms of discrimination in the exercise of their political rights. b) The right to live free of stereotyped patterns of behavior and political, social and cultural practices based on concepts of inferiority or subordination. A "gender stereotype" is considered to be a general opinion or prejudice about the attributes or characteristics that women and men possess or should possess or the social functions that both perform or should perform. A gender stereotype is harmful when it denies a right, imposes a burden, limits women's autonomy, decision-making about their lives and life projects, or their personal or professional development [15].

Article 5. Areas where violence can take place. Violence against women in political life has the purpose or result of impairing or nullifying the recognition, enjoyment or exercise of women's political rights and may take place: a) Within the family or domestic unit or in any other interpersonal relationship; b) In any public sphere, including all public, private and mixed organizations that operate in public life such as political parties; unions; social organizations, including human rights organizations, the media and social media. c) That it be perpetrated or tolerated by the State or its agents, wherever it occurs [15].

Article 6. Manifestations of violence against women in political life. These are "acts of violence against women in political life", among others, those actions, behaviors or omissions against women that, based on their gender: a) (Femicide / Femicide) Cause, or may cause, the violent death of women by reason of their participation or political activity; b) They physically assault one or more women with the object or result of diminishing or nullifying their political rights; c) They sexually assault one or more women or cause abortion, with the object or result of diminishing or nullifying their political rights; d) Make unwanted proposals, touches, approaches or invitations, of a sexual nature, that influence the political aspirations of women and / or the conditions or environment where women carry out their political and public activities; e) Threaten, scare or intimidate in any way one or more women and / or their families, and whose purpose or result is to nullify their political rights, including resignation from the post or function they exercise or postulate; f) Restrict or annul women's right to free and secret voting; g) Defame, slander, insult or carry out any expression that denigrates women in the exercise of their political functions, based on gender stereotypes, with the objective or the result of undermining their public image and / or limiting or nullifying their political rights; h) Threaten, scare or intimidate in any way one or more women and / or their families, and whose purpose or result is to undermine their political rights; i) Threaten, attack or incite violence against human rights defenders for gender reasons, or against those defenders who defend women's rights; j) Unduely use criminal law without foundation in order to criminalize the work of human rights defenders and / or paralyze or delegitimize the causes they pursue; k) They 
discriminate against women in the exercise of their political rights, for being pregnant, childbirth, postpartum, maternity leave or any other justified leave, according to the applicable regulations; 1) They damage in any way elements of the electoral campaign for women, preventing electoral competition from developing under equal conditions; m) Provide electoral institutes with false information or incomplete information on the identity or sex of the candidate and designated person in order to impede the exercise of women's political rights; n) Restrict the political rights of women due to the application of traditions, customs or internal legal systems that violate current human rights regulations; o) Disseminate images, messages or disclose information about women exercising their political rights, by any physical or virtual means, in political-electoral propaganda or in any other that, based on gender stereotypes, transmit and / or reproduce relations of domination, inequality and discrimination against women, with the aim of undermining their public image and/or limiting their political rights; p) Hinder or impede women's access to justice to protect their political rights; q) Impose unjustified and / or abusive sanctions, preventing or restricting the exercise of their political rights under equal conditions; r) Arbitrarily limit or deny the use of any resource and / or attribution inherent to the political position held by women, preventing the exercise of the position on equal terms; s) Forcing women to reconcile or desist when they are in an administrative or judicial process in defense of their political rights; t) Avoid by any means that women in the exercise of their political rights attend any activity that involves decision-making, on equal terms; u) Provide women in the exercise of their political rights with false, erroneous or imprecise information and / or omit information to women that induces the inadequate exercise of their political rights under equal conditions; v) Restrict the use of the word of women in the exercise of their political rights, preventing the right to speak, in accordance with the applicable regulations and on equal terms; w) Impose by gender stereotypes the carrying out of activities and tasks outside the functions and attributions of their position or position or that result in the limitation of the exercise of the political function [15]. $[\ldots]$

\section{General recommendation 35 on gender-based violence against women, updating general recommendation 19}

In its general recommendation number 19 (1992) on violence against women, women, as defined in article 1 of the Convention, included gender-based violence, which is "violence directed against women because it is woman or that affects her disproportionately", and that constituted a violation of her human rights. For more than 25 years, in their practice, States parties have supported the Committee's interpretation. The opinio juris and State practice imply that the prohibition of gender-based violence against women has become a principle of customary international law. General recommendation no. 19 has been a key catalyst in that process. Recognizing that evolution and the work of the Special Rapporteur on violence against women, its causes and consequences, and of the human rights treaty bodies and the special procedures mandate holders of the Human Rights Council, the Committee decided commemorate the 25th anniversary of the adoption of general recommendation no. 19 The Committee decided to commemorate the 25th anniversary of the adoption of general recommendation No. 19. The Committee recognizes that civil society groups, especially women's nongovernmental organizations, have prioritized the elimination of gender-based violence against women; Her activities have had profound social and political repercussions, which have contributed to the recognition of gender-based violence against women as a violation of human rights and the adoption of laws and policies to address it [16].

\section{Jurisprudence 48/2016}

Lorena Cuellar Cisneros and another vs. Electoral Tribunal of Tlaxcala and others. Political Violence for Gender Reasons. The Electoral Authorities are obliged to avoid affecting Electoral Political Rights.

Of the provisions of articles 1, 4, 35 and 41 of the Political Constitution of the United Mexican States; 4, subsection $\mathrm{j}$ ), of the Inter-American Convention to Prevent, Punish, and Eradicate Violence against Women; II and III of the Convention on the Political Rights of Women; and 7, paragraph a), of the Convention on the Elimination of All Forms of Discrimination against Women; as well as that established in the Protocol to Address Political Violence Against Women, it is concluded that political violence against women includes all those actions or omissions of people, servants or public servants who address a woman because she is a woman, have a differentiated impact on them or affect them disproportionately, with the object or result of impairing or nullifying their political-electoral rights, including the exercise of office. The right of women to a life free from discrimination and violence, translates into the obligation of all authorities to act with due diligence and jointly to prevent, investigate, punish and repair a possible impact on their rights. Consequently, when gender-based political violence is alleged, a public order problem, the electoral authorities must carry out an analysis of all the facts and grievances exposed, in order to make effective access to justice and due process. Due to the complexity involved in cases of gender-based political violence, as well as the invisibility and normalization in which these types of situations are found, it is necessary that each case be analyzed in a particular way to define whether or not it is gender-based violence and, where appropriate, delineate the actions that will be taken to avoid impunity and to repair the damage to the victims [17]. 


\section{Inter-American Human Rights System}

It contains the main instruments of the interAmerican system for the protection of human rights. Its objective is to serve as a guide for users of the system. Here are the different declarations, conventions and protocols from which the mandates and functions of the organs of the system (the Inter-American Commission on Human Rights and the Inter-American Court of Human Rights) are derived, as well as the obligations of the Member States of the Organization. of the American States in the field of human rights. Updated January 24, 2020. The Basic Documents include the American Declaration of the Rights and Duties of Man (hereinafter "the American Declaration") and the American Convention on Human Rights (hereinafter "the American Convention"). Following are the InterAmerican Convention on torture, the additional protocols to the American Convention on economic, social, and cultural rights and on the abolition of the death penalty, and the Conventions to prevent, punish, and eradicate violence against the woman "Belém do Pará Convention"; the forced disappearance of people; discrimination against people with disabilities; racism, racial discrimination and related forms of intolerance and all forms of discrimination and intolerance; on the protection of the human rights of older persons, as well as a list of the OAS States that are signatories to said treaties, and the current status of said ratifications[18].

Likewise, the OAS Charter, the InterAmerican Democratic Charter and the Social Charter of the Americas are included. Additionally, the following statements approved by the IACHR are included: Principles on Freedom of Expression; Principles and Good Practices on the Protection of Persons Deprived of Liberty in the Americas; Principles on Memory Policies in the Americas; Inter-American Principles on the Human Rights of All Migrants, Including Refugees, Stateless Persons, and Victims of Human Trafficking. Updated to January 24, 2020 [18].

\section{Inter-American Convention to Prevent, Punish, and Eradicate Violence against Women (Convention of Belém do Pará) \\ The Inter-American Convention to Prevent,} Punish, and Eradicate Violence against Women, known as the Belém do Pará Convention, held in the city of Belém do Pará, Brazil, on June 9, 1994, defines violence against women, establishes the women's right to live a life free of violence and highlights violence as a violation of human rights and fundamental freedoms. [19]

It proposes for the first time the development of mechanisms for the protection and defense of women's rights as fundamental to fight against the phenomenon of violence against their physical, sexual and psychological integrity, both in the public and private spheres, and their demand within society. The effective implementation of the Convention requires a process of evaluation and continuous and independent support, for which the Follow-up Mechanism of the Convention of Belém do Pará was created in 2004 [19].

The MESECVI is a systematic and permanent multilateral evaluation methodology, based on a forum for exchange and technical cooperation between the States Parties to the Convention and a Committee of Experts [19].

The MESECVI analyzes the progress in the implementation of the Convention by its States Parties, as well as the persistent challenges in the State responses to violence against women.

It is the Inter-American Convention with the highest number of ratifications of the Member States of the Organization of American States (OAS)[19].

Among the most relevant aspects related to the protection of women, the Convention states: InterAmerican Convention to Prevent, Punish, and Eradicate Violence against Women (Convention of Belém do Pará) PREAMBLE [19].

\section{The states parties to this convention}

RECOGNIZING that unrestricted respect for human rights has been enshrined in the American Declaration of the Rights and Duties of Man and in the Universal Declaration of Human Rights and reaffirmed in other international and regional instruments; [19].

AFFIRMING that violence against women constitutes a violation of human rights and fundamental freedoms and limits the recognition, enjoyment and exercise of such rights and freedoms in whole or in part to women;

CONCERNED that violence against women is an offense to human dignity and a manifestation of historically unequal power relations between women and men [19].

RECALLING the Declaration on the Eradication of Violence against Women, adopted by the Twenty-fifth Assembly of Delegates of the InterAmerican Commission of Women, and affirming that violence against women transcends all sectors of society regardless of class, race or ethnic group, income level, culture, educational level, age or religion and negatively affects their own foundations;

CONVINCED that the elimination of violence against women is an indispensable condition for their individual and social development and their full and equal participation in all spheres of life, and, [19]

CONVINCED that the adoption of a convention to prevent, punish, and eradicate all forms of violence against women, within the framework of the 
Organization of American States, constitutes a positive contribution to protect the rights of women and eliminate situations of violence that may affect them, HAVE AGREED as follows: [19]

\section{$[\ldots]$}

Art. 5 Every woman may freely and fully exercise her civil, political, economic, social and cultural rights and will have full protection of those rights enshrined in regional and international human rights instruments. States Parties recognize that violence against women prevents and nullifies the exercise of these rights [4].

\section{The Spotlight Initiative, to eliminate violence against women and girls}

The Spotlight Initiative is a joint campaign by the European Union and the United Nations aimed at eliminating all forms of violence against women and girls.

The initiative's name - Spotlight, which means "spotlight" in English - reminds us that this violence often takes place in the dark, is denied or hidden. With our efforts, we can bring it to the public eye, make it the center of attention, and take steps to eliminate it. So, we can make gender equality and the empowerment of women a reality [20].

The campaign also highlights the importance of investing specifically in women and girls, an essential condition for achieving sustainable development in accordance with the 2030 Agenda.

It is an unprecedented, global and multi-annual initiative, which has had an initial investment of 500 million euros, with the European Union as the main contributor. It has the collaboration of other donors and partners who have expanded the scope and magnitude of the campaign. To finance it, a United Nations trust fund is used, administered by the Office of the Multiple Donor Trust Funds, supported by the United Nations Development Program (UNDP), the United Nations Population Fund (UNFPA) and UN Women, and supervised by the Executive Office of the SecretaryGeneral [20].

\section{Women's participation and progress towards the recognition of political violence against women \\ The participation of women in decision-} making spheres has been a gradual process, the product of various struggles by organizations, activists, academics, and legislators that have promoted political agendas in favor of women's rights, particularly to guarantee political-electoral rights. Following the attempt to implement an affirmative action measure such as gender quotas, in 2014, with the politicalelectoral reform, parity between men and women in federal and state candidacies was raised to a constitutional rank, which was a transcendental step, because it gave the guideline to establish the recognition of the same opportunities of access to positions of political representation; however, in reality it has been disproportionately translated at various times. In this sense, in the democratic history of Mexico, only nine women have been governors; in $2017,17 \%$ of the Secretariats of State had a woman as their head, while the rest were occupied by men. Likewise, in the 2018 elections, of the 48 candidates to occupy the governorship of nine entities, only 11 were women. It was not until 2019 that an important advance was observed in the participation of women, since there were at least 554 mayors, 548 local deputies and 241 federal ones. Although each federal entity has had its own progress, in total, $33 \%$ of popularly elected positions were held by women, via suffrage [7].

Now, the advance in the laws, and in practice, has gone through various situations that have diminished the participation of women, since being spaces traditionally dominated by men, actions of nonconformity and irregularity in electoral processes have been manifested, for example, within political parties, leaders do not allow women candidates or elected to make decisions related to the campaign and the form of administration; They deny access to necessary and relevant information to exercise their position or require them to promote certain topics and projects. They tend to minimize the knowledge and capacity of women to carry out their functions. In addition, they carry out actions that sexualize women, as the parties spread sexist propaganda, reproducing gender stereotypes. Another way in which they prevent the professional training of women is when the parties do not carry out actions to strengthen their political leadership. In 2016, the National Electoral Institute reported this through the audit of resources, in which the Institute observed the absence of measures aimed at providing tools to women for their political empowerment [7].

In relation to the above, let us remember that political violence against women has various manifestations consisting of hindering their participation, through threats, intimidation, assaults, among others, which aim to undermine or nullify recognition, enjoyment and/or exercise of the politicalelectoral rights of women. Such violence may include physical, psychological, economic, sexual, property, or feminicidal violence. In addition to this, we must add that this type of violence is invisible and normalized, even with institutional efforts in preparing protocols to deal with it, since it must be recognized that these efforts have made possible the existence of routes of orientation to victims and mechanisms for its prevention and care. However, the fight for the typification of political violence against women has involved a long process, and one that was recently recognized, since on April 13 of this year the decree was published in the Official Gazette of the Federation (DOF) that reforms various provisions of general laws 
to incorporate the crime of political violence against women based on gender. In the reform made to the General Law on Women's Access to a Life Free of Violence, political violence is defined as: Any action or omission, including tolerance, based on gender elements and exercised within the public or private sphere, whose purpose or result is to limit, nullify or impair the effective exercise of the political and electoral rights of one or more women, access to the full exercise of the powers inherent to their position, work or activity, the free development of public function , decision-making, freedom of organization, as well as access and exercise of prerogatives, in the case of precandidacies, candidacies, functions or public positions of the same type [7].

This step is transcendental because it highlights that the Office of the Attorney General of the Republic may create temporary special commissions for investigations of various crimes, including political violence against women. In addition to having a focus on access to truth, justice, comprehensive compensation for damage and guarantees of non-repetition. The foregoing implies substantive progress in this area, since it is necessary to provide timely follow-up, have reports that account for political violence against women with precise indicators to assess the obstacles that women face and adopt necessary measures for your observation and attention. In the latest report of the Specialized Prosecutor for Electoral Crimes (FEPADE) for the month of April, said instance indicates that no complaints were registered for incidents related to gender-based political violence. This may be due to the lack of visibility and recognition of the violence suffered by women themselves, which is why it is necessary to implement awareness strategies in this regard [7].

\section{Women holding popularly elected positions}

In 10 years, Mexican women in politics achieved 554 mayoralties, 548 local and 241 federal deputations, 63 senatories and two governorships, that is, a total of 1,408 public offices and the number is increasing [21].

The constant struggle of Mexicans to achieve gender parity in the country's politics has caused the number of women at the head of a popularly elected office to increase 240 percent in the past decade, from 414 cases in 2009 to 1,000408 currently.

In 2019 there were 554 mayors, 548 local and 241 federal deputies, as well as 63 senators and two governors. In total, 33 percent of the public servants who obtained their jobs, via public suffrage, are women. This proportion shows the great progress of this sector in the country, since, in 2009, only 9.8 percent of public positions were held by a female person [21].
Despite the above, there are still great opportunities for growth if it is considered that of the 4,220 places that were put to the vote, 66.8 percent are still managed by men. Gender parity in politics is a topic that has been discussed in recent years in various forums; However, the greatest disparity is observed in the municipal presidencies, where for each woman there are four men, as well as in the governors' offices, where there are only two cases: Claudia Sheinbaum in Mexico City and Claudia Pavlovich in Sonora [21].

According to the National Municipal Information System of the National Institute for Federalism and Municipal Development (INAFED), 22.5 percent of the 2,455 mayorships in the country are under the orders of a woman. Official records reveal that 274 municipal presidents, equivalent to 49.4 percent of the 554 in the country, are located in the south: Campeche, Chiapas, Guerrero, Morelos, Oaxaca, Puebla, Quintana Roo, Tabasco, Tlaxcala, Veracruz and Yucatan. Another 171 are in charge of municipalities in the center of the country, which includes Aguascalientes, Colima, Mexico City, Guanajuato, Hidalgo, Jalisco, State of Mexico, Michoacán, Nayarit, Querétaro, San Luis Potosí and Zacatecas [21].

The rest work in municipalities of Baja California, Baja California Sur, Coahuila, Chihuahua, Durango, Nuevo León, Sinaloa, Sonora and Tamaulipas. The mayorships conquered by women have seen a sustained increase since 2009 when there were only 116 municipal presidents in the country. According to INAFED data, in 10 years the municipalities headed by a female grew 377.5 percent. Gender parity in local congresses is almost a reality, since 49.1 percent are women, according to the third National Census of State Legislative Powers published last November by the National Institute of Statistics and Geography. The census reveals that of the 1,133 local deputies registered last year, 547 are women, which means a substantial increase of more than 10 percent compared to last year. At the federal level, a similar reality is lived, since of the 628 legislators that make up the Congress of the Union, 304 are women, which is equivalent to $48.4 \%$ of federal deputies and senators. Currently there are only two governors: Claudia Sheinbaum and Claudia Pavlovich. They are part of a reduced list of only nine women who have presided over the Executive Power in a state [21].

\section{Mexico begins the fight against political violence against women \\ On April 14, 2020, reforms to combat political} violence against women came into effect; The decree modifies eight laws to combat and sanction political violence against women based on gender. This standard was approved by the Congress of the Union, on March 18,2020 [22]. 
The Official Gazette of the Federation (DOF) published the decree that impacts eight laws in order to provide greater protection to the political and electoral rights of women, and to punish even those who commit this type of violence [22].

The following general laws were amended: 1.On Women's Access to a Life Free of Violence; 2.- of Electoral Institutions and Procedures; 3.- of the System of Means of Contest in Electoral Matters; 4.- of Political Parties; 5.- Regarding Electoral Crimes; 6.- of Administrative Responsibilities; 7.- Organic Law of the Office of the Attorney General of the Republic; and, 8.Organic Law of the Judicial Power of the Federation [22].

Based on this decree, gender-based political violence against women is included as a modality, which was defined as: "any action or omission, including tolerance based on gender elements and exercised within the public or private sphere, whose purpose or result is to limit, nullify or impair the effective exercise of the political and electoral rights of one or more women". It also includes their access to the full exercise of the powers inherent to their position, work or activity, the free development of the public function, decision-making, freedom of organization, as well as access and exercise of prerogatives, in the case of candidacies and precandidacies or who are already civil servants or hold public office. In addition, it specifies that whoever commits political violence against women will be "that person who seeks to undermine the rights of women or discriminate against them because of any situation[22]".

The conduct can be indistinctly perpetrated by state agents, hierarchical superiors, work colleagues, leaders of political parties, militants, sympathizers. Also, by pre-candidates, pre-candidates, candidates or candidates nominated by the political parties or their representatives; the media and its members, by an individual or by a group of individuals. On the other hand, the decree stipulates that the National Electoral Institute, Local Public Organizations, political parties, pre-candidates and candidates, must guarantee the principle of gender parity in the exercise of political and electoral rights [22].

Parity will be guaranteed with the allocation of 50 percent women and 50 percent men in nominations for popularly elected positions and in appointments by appointment. Political parties will be required to promote the rights of women, respecting gender parity and training their militancy. In turn, the decree proposes sanctions and reparation of the damage, depending on the severity of the situation. Among the sanctions, it is worth reducing the financing of political parties by up to 50 percent, canceling their registration, canceling the prerogatives of the aggressor, and in more serious cases, a penalty of four to six years in prison and a 200 to $300-$ day fine. Finally, it provides that to aspire to be a legislator, you must not be accused of having exercised political violence against women on the basis of gender [22].

\section{CONCLUSIONS}

It is said that when a woman has power, she is capable of transforming her environment and that of those around her, however, women's access to political power was, is and will be the subject of discussion and debate, mainly among those who still, in Mexico, despite the efforts that women have made for decades and in different settings, do not consider that they have the capacity, along with men, to occupy with dignity the managerial positions and positions of popular election, ignoring the profiles, experience, capacities, aptitudes, virtues and qualities of these, and with this, preventing, limiting and / or making it difficult for them to exercise their human rights, particularly, to participate in public and political decisions in the country, since, unfortunately, women they are still mostly invisible to spaces for real decision-making, and therefore are victims of political violence.

Mexican women suffer high rates of violence of all kinds, in the home, workplace harassment, sexual abuse, femicide and aggression in the exercise of their political-electoral rights, and one of the great errors that have been historically committed in our country, is the fact that gender-based violence has been classified as an issue and a matter exclusively for women, when it also concerns men, and it has been and continues to be one of the main barriers to the exercise of citizenship of the Mexican woman to participate in the public and political decisions of the country.

While women did not challenge power, no one questioned their suitability or ability to run for office. The problem was when they gained power, kept competitive nominations, became threats to the status quo, and acceded to positions that they believed belonged to them. Despite significant momentum by some partisan sectors, women's movements, and electoral administration and justice, Mexican party candidates and militants continue to face strong obstacles when they want to become leaders of their party organizations or when they compete for positions of popular representation, in particular at the local level [25].

Unfortunately, political violence against women based on gender, which is the obstacle they face when they want to exercise their political-electoral rights, for a long time was not recognized as a punishable criminal, electoral or administrative conduct, it could only be sanctioned through the configuration of other behaviors that were contemplated and generated responsibilities in these ways, despite the fact that many of the behaviors that involve genderbased political violence against women constitute 
crimes recognized by law. if a woman was a victim of political violence, she could only initiate a criminal action denouncing the crimes that had been set up against her, which forced the attorney general's office to which she denounced (if it was her competence) to investigate the crimes and find the whereabouts of those responsible for presenting them to a criminal judge [5].

To understand more about inequality in the political sphere for women, for example, it should be noted that in the democratic history of Mexico only nine women have been governors, the first in 1979 in the state of Colima and the most recent in Sonora and in Mexico City, and that during the last 2018 elections, of 48 candidates for the governorship in nine entities, only 11 were women; In more than 40 years and until the last administration (2012-2018), of a total of 236 members of the federal government cabinets, only 23 women had held the position of Secretaries of State. In 2017, only $17 \%$ of the Secretaries of State had a woman as their head, while in $83 \%$ of the Secretariats, the head was a man. Currently, in the government of President Andrés Manuel López Obrador, parity was achieved with eight women and eight men in the cabinet; Regarding the Federal Judicial Power, in the case of the Plenary of the Supreme Court of Justice of the Nation, women represent only $18 \%$ and in the Superior Chamber of the Electoral Court, the percentage of women magistrates corresponds to $28 \%$, while, in the Federal Judicial Council, the directors make up about $29 \%$ of the total of those who comprise it [24].

Since 1993, efforts have been made and various actions have been taken to promote and increase the substantive participation of women in political life, such as quota and / or gender parity laws at the constitutional level, and presented contributions that the jurisdictional bodies have made in the matter, as well as the reforms to the regulations that have been implemented for the same purpose, all to promote their access and exercise of power in democratic institutions and to advance towards policies that guarantee respect for their rights to women, thereby counteracting a series of exclusionary, discriminatory, violent, misogynistic and sexist practices of politics, which for years they have suffered and continue to do son.

Definitely, political parties play a fundamental role in the issue of political violence against women and must confront it, that is, politicians must change their way of doing politics and thereby eradicate any type of gender violence. The task of politicians and their parties is key in the fight against political violence. The parties must immediately exercise concrete actions that demonstrate their fight against political violence against women.

Political parties are the ones that control the access and advancement of women in political power structures. In order to achieve leadership, women must rise within parties, which have the exclusive ability to nominate candidates for public office, and unfortunately, political parties have historically been characterized as sexist structures that do not incorporate their ranks to women on equal terms with men, preventing them from accessing leadership positions [9].

Contrary to what is usually thought, the political parties have not yet seen the benefits of having women as their representatives to positions of popular representation or as their party leaders; many parties have resisted and have hindered the path to greater participation of women in Mexican and Latin American politics. Even so, even reluctantly, in Mexico progress has been made in the symbolic and descriptive representation of women in institutions. Despite them, and often even against the party leaders themselves, some progress has been made. It will be a task that will probably take years and requires daily learning from citizens and political elites about how to work together and in a coordinated manner on an effective gender agenda, which guarantees the implementation of a parity democracy. Eradicating situations of violence is not a minor issue and parties are key actors in promoting this democratic agenda.

Despite the fact that party leaders must allocate a percentage of the public money they receive as prerogatives for the strengthening of women's political leadership, they tend to be reluctant to use that money and even tend to carry out activities unrelated to the issue, despite the fact that are budgeted in their Annual Work Programs (PAT) that they deliver to the National Electoral Institute (INE), and they prefer to pay fines for under-exercising the labeled budget than to comply with what is required by law, thereby violating women's rights. The inspection activity carried out by the INE in 2016 revealed how the parties in the states did not use the money allocated to strengthening female leadership activities, in addition, the parties disseminate sexist propaganda and position women as objects ("things") to be seen at the end of the campaign reproducing stereotypical gender roles. Even many partisan leaders play with the expectations of women by telling them that they must be trained in order to have a candidacy (something that is never required of militant men), and then they often nominate those who did not participate in the training or training courses of the leadership [8].

Many women who have participated in an electoral campaign and/or have wanted to hold positions of political representation have faced situations of violence, whether physical, psychological and/ or symbolic, because they are women. Despite the regulatory advances, the General Law on Electoral Crimes did not define gender-based political violence and, although in 2016, various public institutions such as the TEPJF, the INE, and FEPADE, among others, prepared and signed the "Protocol to Address Political 
Violence against Women", this type of violence continues to increase in the country, in a more general context of structural violence.

The entry in validity of the reform to 10 articles of the Political Constitution of the United Mexican States on June 6, 2019, which comprise various laws and establish sanctions in terms of electoral, criminal and administrative responsibilities legislation, will have an impact significant in the electoral political life of the country and specifically in the electoral processes to be held the next year, in addition, it marks a historic moment and an unprecedented achievement to guarantee the political rights of women, because it will ensure that half of the positions of the decision is made for women in the three branches of the State, in the three levels of government, in the autonomous bodies, in the candidacies of political parties for positions of popular election, as well as in the election of representatives to city councils in the municipalities with indigenous population; in addition, the language that makes visible and includes women is incorporated.

There is still much to be done and defined, for example, establishing who should investigate cases related to gender violence when local and federal issues are involved, what authority will be in charge of investigating and punishing political violence for gender reasons at headquarters. Legislation, how the indigenous communities' right to self-determination can be reconciled when their uses and customs may restrict the political participation of women, determining whether uses and customs can constitute an electoral crime, etc.

As a country, it is essential to focus on the objective of advancing in the identification, visibility and fight against political violence against women and it must be a job for everyone: men and women, politicians and non-politicians, from the three levels of government, from political parties, electoral bodies, academics, women's groups from civil society, state institutions that fight for women's rights, international cooperation agencies, etc. There is still a long way to go on the subject and the commitment of both empathetic, fair, brave and tenacious women and men is essential, in addition, structural changes are still required for women to have real and effective joint participation, that is, it not only implies that women are fifty percent of those who make decisions, but that they do so without any type of discrimination or violence. In addition, it is essential to adopt measures so that they can reconcile family and work life, since it is a factor that does not allow them to carry out their political development in conditions of equality with men.

\section{REFERENCES}

1. Domínguez, P. (2015). Excelsior. Retrieved on 07/07/2020, from https://www.excelsior.com.mx: https://www.excelsior.com.mx/opinion/paoladominguez-boullosa/2015/12/02/1060806

2. OMS. (s.f.). OMS. Retrieved on 22 de 07 de 2020 , from https://www.who.int: https://www.who.int/topics/violence/es/\#: :text=La $\% 20$ violencia\%20es\%20el\%20uso,de\%20desarroll o\%20o\%201a\%20muerte.

3. OMS. (s.f.). OMS. Retrieved on 22 of 07 of 2020, from https://www.who.int/: https://www.who.int/es/news-room/factsheets/detail/violence-against-women

4. Cámara de Diputados. (s.f.). Cámara de Diputados. (2020). (CELIG, Editor) Retrieved on 22 of 07 2020, from http://www3.diputados.gob.mx/: http://www3.diputados.gob.mx/camara/content/do wnload/336499/1201774/file/ViolenciaPoliticalCo mpleta_r.pdf.

5. CNDH, C. N. (s.f.). (2020). Comisión Nacional de Derechos Humanos. (CNDH, Editor) Retrieved on 21 of 07 of 2020, from https://www.cndh.org.mx: https://www.cndh.org.mx/sites/all/doc/OtrosDocum entos/Doc_2018_056.pdf

6. TEPJF. (2016). Tribunal Electoral del Poder Judicial de la Federación. Retrieved on 30 of 07 of 2020, from https://www.te.gob.mx: https://www.te.gob.mx/protocolo_mujeres/media/fi les/7db6bf44797e749.pdf

7. Chavarría, C., Rangel, A., \& Camacho, F. (2020). (T. E. México, Ed.) Electio(17), 75-84. Retrieved on 22 of 07 of 2020, from https://www.tecdmx.org.mx/wpcontent/uploads/2020/07/Electio_1ersemestre2020 _w.pdf?fbclid=IwAR2BCaC9ivtQ3upvKSG8o6yoffxfBHi9lx06BdkErUQZ4B6eOMFjhZ0_M

8. Instituto Nacional Electoral. (2017). https://www.ine.mx. Retrieved on 27 of 07 of 2020, from Instituto Nacional Electoral: https://www.ine.mx/wp-

content/uploads/2019/04/la_representacion_politica _de_las_mujeres_en_mex.pdf

9. Fernández, A. (2011). REDALYC. (U. A. Xochimilco, Editor) Retrieved on 23 of 07 of 2020 , from www.redalyc.org: https://www.redalyc.org/pdf/595/59520783010.pdf

10. Pimienta, X. (2018). www.forbes.com.mx. Retrieved on 23 of 07 of 2020, from FORBES: https://www.forbes.com.mx/juanitas-y-manuelitasla-historia-de-repite/

11. Observatorio de Participación Política de las mujeres en Veracruz. (2017). Observatorio de Participación Política de las mujeres en Veracruz. Retrieved on 22 de 07 of 2020, from http://www.plataformaivm.net:

http://www.plataformaivm.net/observatorio/notas/v iolencia-politica-de-genero-impide-igualdad-enelecciones/

12. Constitución Política de los Estados Unidos Mexicanos [Const.]. (1917). Artículos 1,4, 34 [Título Primero], 34 [. H. Congreso de la Unión. 
Retrieved on 23 of 07 of 2020, from http://www.diputados.gob.mx:http://www.diputado s.gob.mx/LeyesBiblio/pdf/1_080520.pdf

13. Plenilunia. (2019). https://plenilunia.com. Retrieved on 22 of 07 of 2020, from https://plenilunia.com/noticias-2/celig-presentaanalisis-violencia-politica-en-razon-degenero/60985/?cn-reloaded $=1$

14. INCIDE SOCIAL. (2020). Retrieved on https://incidesocial.org/protocolo-para-la-atencionde-la-violencia-contra-las-mujeres-en-razon-degenero/

15. OEA. (2017). https://www.oas.org. Retrieved on 22 of 07 of 2020, from https://www.oas.org/en/cim/docs/ViolenciaPolitica -LeyModelo-ES.pdf

16. ONU. (2017). ONU. Retrieved on 23 of 07 of 2020, from https://tbinternet.ohchr.org/: https://tbinternet.ohchr.org/_layouts/15/treatybodye xternal/Download.aspx?symbolno=CEDAW/C/GC 135\&Lang=en

17. México Justia. (s.f.). México Justia. Retrieved on 28 of 07 of 2020 , from https://mexico.justia.com:https://mexico.justia.com /federales/jurisprudencias-tesis/tribunalelectoral/jurisprudencia-48-2016/

18. OEA. (s.f.). OEA. Retrieved on 22 of 07 of 2020 , from http://www.oas.org: http://www.oas.org/es/cidh/mandato/Basicos/introd uccion.asp

19. OEA. (s.f.). OEA. Retrieved on 22 of 07 of 2020 , from https://www.oas.org: https://www.oas.org/es/mesecvi/docs/BelemDoPar a-ESPANOL.pdf
20. ONU. (s.f.). ONU. Retrieved on 06 of 08 of 2020, from https://www.un.org/es: https://www.un.org/es/spotlight-initiative/

21. López, R. (2020). https://www.milenio.com. Retrieved on 22 of 07 of 2020, from MILENIO: https://www.milenio.com/politica/mujeres-ocupanmil-408-cargos-publicos-cifra-ascenso

22. Maritano, A. (2020). Diario Jurídico. Retrieved on 28 of 07 of 2020, from https://www.diariojuridico.com: https://www.diariojuridico.com/mexico-empiezael-combate-de-la-violencia-politica-contra-lasmujeres/

23. INMUJERES, I. N. (2019), https://www.gob.mx/inmujeres. Retrieved on 22 of 07 of 2020, from Instituto Nacional de las Mujeres: https://www.gob.mx/inmujeres/articulos/paridaden-todo-50-mujeres-y-50-hombrees-en-la-toma-dedecisiones

24. Cámara de diputados. (s.f.). http://www3.diputados.gob.mx. Retrieved on 27 of 07 of 2020, from Cámara de Diputados LXIV Legislatura: http://www3.diputados.gob.mx/camara/content/do wnload/336499/1201774/file/ViolenciaPoliticalCo mpletaBAJA.pdf

25. Freidenberg, F., \& Osornio, M. (2017). https://www.ine.mx. (I. N. ELECTORAL, Editor) Retrieved on 22 of 07 of 2020, from INE: https://www.ine.mx/wpcontent/uploads/2019/04/la_representacion_politica _de_las_mujeres_en_mex.pdf. 